\title{
Digital technologies in the care of people with diabetes during the COVID-19 pandemic: a scoping review
}

\author{
Tecnologias digitais no cuidado a pessoas com diabetes durante a pandemia de COVID-19: \\ revisão de escopo
}

Tecnologías digitales en la atención de personas con diabetes durante la pandemia de COVID-19: revisión del alcance

How to cite this article:

Negreiros FDS, Araújo AL, Mattos SM, Moreira TR, Cestari VRF, Silva LMS, Moreira TMM. Digital technologies in the care of people with diabetes during the COVID-19 pandemic: a scoping review. Rev Esc Enferm USP. 2021;55:e20210295. https://doi.org/10.1590/1980-220X-REEUSP-2021-0295.

\author{
Francisca Diana da Silva Negreiros ${ }^{1}$ \\ (iD) Açucena Leal de Araújo ${ }^{2}$ \\ iD Samuel Miranda Mattos ${ }^{3}$ \\ (iD) Tatiana Rebouças Moreira ${ }^{1}$ \\ (iD) Virna Ribeiro Feitosa Cestari ${ }^{2}$ \\ (iD) Lucilane Maria Sales da Silva² \\ (D) Thereza Maria Magalhães Moreira ${ }^{2,3}$ \\ ${ }^{1}$ Universidade Federal do Ceará, Hospital \\ Universitário Walter Cantídio, Fortaleza, CE, Brazil. \\ ${ }^{2}$ Universidade Estadual do Ceará, Programa de \\ Pós-Graduação em Cuidados Clínicos em \\ Enfermagem e Saúde, Fortaleza, CE, Brazil. \\ ${ }^{3}$ Universidade Estadual do Ceará, Programa de \\ Pós-Graduação em Saúde Coletiva, Fortaleza, \\ CE, Brazil.
}

\begin{abstract}
Objective: To map evidence on the use of digital technologies in the care of people with diabetes during the COVID-19 pandemic. Method: This is a scoping review, based on the JBI manual, which included scientific articles and gray literature from nine primary and seven secondary databases. Articles were independently assessed by two reviewers. Rayyan ${ }^{\circledR}$ was used to select the studies. The description of study characterization is presented in a table and tables, ending in a narrative synthesis. Results: A total of 1,964 studies were identified and, after selection, 23 publications remained for analysis. It turned out that telemedicine was used in all studies and remote consultation support technologies included continuous glucose monitoring devices, glucose data analysis software, insulin delivery systems, applications, audio and/or voice communication devices, which facilitated remote diabetes mellitus monitoring and management. Conclusion: Telehealth, monitoring technologies, insulin delivery systems and communication devices were tools used to monitor patients with diabetes during the pandemic.
\end{abstract}

\section{DESCRIPTORS}

Technology; Educational Technology; Mobile Applications; Coronavirus Infections; Severe Acute Respiratory Syndrome; Diabetes Mellitus. 


\section{INTRODUCTION}

The COVID-19 pandemic imposed the need for new strategies and adaptations of health services to act in the face of the reality of social distancing. This fact provided an opportunity to improve processes and flows in the use of digital health technologies, as these tools can improve access and quality of care, being effective in facilitating contact between health professionals and patients ${ }^{(1)}$.

A study identified that most of the technologies implemented in the pandemic included healthcare providers and consumers, due to the extreme measures imposed to prevent the spread of COVID-19, interrupting the provision of health services for many patients, especially those with chronic conditions ${ }^{(2)}$. In this perspective, multiple countries sought to adopt innovations in health, with the aim of providing continuous care to clients with chronic conditions and at risk for COVID-19, such as patients with diabetes mellitus (DM).

Since the beginning of the new coronavirus pandemic, a bidirectional relationship between COVID-19 and DM has been pointed out. On the one hand, people with DM are at greater risk of developing complications when they have COVID-19, and on the other hand, SARS-CoV-2 could act as a diabetogenic agent as it is capable of causing direct damage to the pancreas, which can worsen hyperglycemia and even induce DM in individuals without the disease ${ }^{(3)}$.

Moreover, people with DM infected with SARS-CoV-2 have a higher rate of hospitalization, severe pneumonia, and higher mortality compared to individuals without DM. Therefore, blood glucose and comorbidity management must be individualized to reduce the incidence of complications and reduce the burden on health systems ${ }^{(3)}$. Thus, it is essential to use digital technologies with these patients, during the pandemic, to continuously monitor the clinic, allowing better management of the disease.

Although studies on prevention, treatment and COVID-19 in DM have been developed ${ }^{(3-5)}$, so far few studies on the use of digital technologies in health ${ }^{(2)}$ and in the care of people with DM during the pandemic have been identified ${ }^{(6)}$, it is necessary to update and continue mapping new evidence to support technology-mediated DM care during the pandemic. Therefore, the objective was to map the evidence on the use of digital technologies in the care of people with DM during the COVID-19 pandemic.

\section{METHOD}

\section{Design of Study}

This is a scoping review, based on the methodological framework developed by the Joanna Briggs Institute $(\mathrm{JBI})^{(7)}$ and on the Preferred Reporting Items for Systematic reviews and Meta-Analyses extension for Scoping Reviews (PRISMA-ScR, see Supplementary File 1$)^{(8)}$. The review was registered in the Open Science Framework (Osf.io/wqd4p), with identification DOI 10.17605/OSF.IO/WQD4P.

The review was developed in five steps ${ }^{(7,9)}$ : (1) research question identification; (2) survey of relevant studies, which would enable the breadth and scope of the review; (3) study selection according to predefined criteria; (4) data mapping; and (5) presentation of results.

\section{Data Collection}

To structure the research question (step 1), the mnemonic PCC (Population, Concept, Context) was used ${ }^{(7)}: \mathrm{P}$ consisted of people with DM; $\mathrm{C}$ in digital technologies; and the $\mathrm{C}$ in COVID-19. Thus, the guiding question was: what is the evidence on the use of digital technologies in the care of people with DM during the COVID-19 pandemic?

The elaboration of the search equation received assistance from a librarian in the health area, for greater sensitivity and refinement. The searches took place on March 17, 2021 in the Online Medical Literature Analysis and Retrieval System (MEDLINE) via PubMed, MEDLINE via Elton B. Stephens Company (EBSCO), MEDLINE via Virtual Health Library (VHL), Latin American and Caribbean Health Science Literature (LILACS), Web of Science, Scopus, Cumulative Index to Nursing and Allied Health Literature (CINAHL), Cochrane Library and Embase databases.

Gray literature was retrieved from seven sources: Google Scholar, Brazilian Digital Library of Theses and Dissertations (BDTD - Biblioteca Digital Brasileira de Teses e Dissertações), Theses and Dissertations Catalog (CTD - Catálogo de Teses e Dissertaçôes) of the Coordination for the Improvement of Higher Education Personnel (CAPES - Coordenação de Aperfeiçoamento de Pessoal de Nivel Superior), OpenGrey, New York Academy of Medicine (NYAM) Library, ProQuest Dissertations and Theses (PQDT) and Open Access Theses and Dissertations (OATD). The retrieval of documents in Google Scholar was performed on the first ten pages, with a 2019-2021 time filter, as the theme emerged at the end of 2019. The search strategy was built with three controlled vocabularies in health, Health Science Descriptors (DECS), Medical Subject Headings (MeSH), EMTREE and natural language, together with Boolean operators AND and OR, to obtain a wide spectrum of results in different databases ${ }^{(10)}$. In the databases surveyed, we used the structure presented in Chart 1.

\section{Selection Criteria}

As eligibility criteria for this scoping review, the following were established: publications on care for people with DM mediated by digital technologies during the pandemic, from the year 2019, beginning of the first COVID-19 reports, without language restrictions. As for study design, primary and secondary, empirical, quantitative and qualitative research of any design or methodology were chosen. Letters to the editor, abstracts in event proceedings, incomplete articles, studies in the design phase or without results were excluded.

After the search developed according to the strategy outlined above, the studies were selected (step 3). The results obtained in the databases were exported to the Rayyan ${ }^{\circledR}$ reference manager, developed by the Qatar Computing Research Institute (QCRI) ${ }^{(11)}$, for removal of duplications, selection and screening of studies by two researchers, independently, with differences being resolved with the participation of a third examiner. The first phase consisted of reading titles and abstracts. Studies that met the 
Chart 1 - Search strategy for document retrieval. Fortaleza, CE, Brazil, 2021.

\begin{tabular}{|c|c|c|c|}
\hline & $\mathbf{P}$ & C & C \\
\hline Extraction & $\begin{array}{c}\text { People with diabetes } \\
\text { mellitus Diabetes Mellitus }\end{array}$ & Digital technologies & COVID-19 \\
\hline Conversion & Diabetes Mellitus & Technology & Coronavirus Infections \\
\hline Construction & $\begin{array}{c}\text { diabetes OR diabetic OR } \\
\text { "diabetic patient" }\end{array}$ & 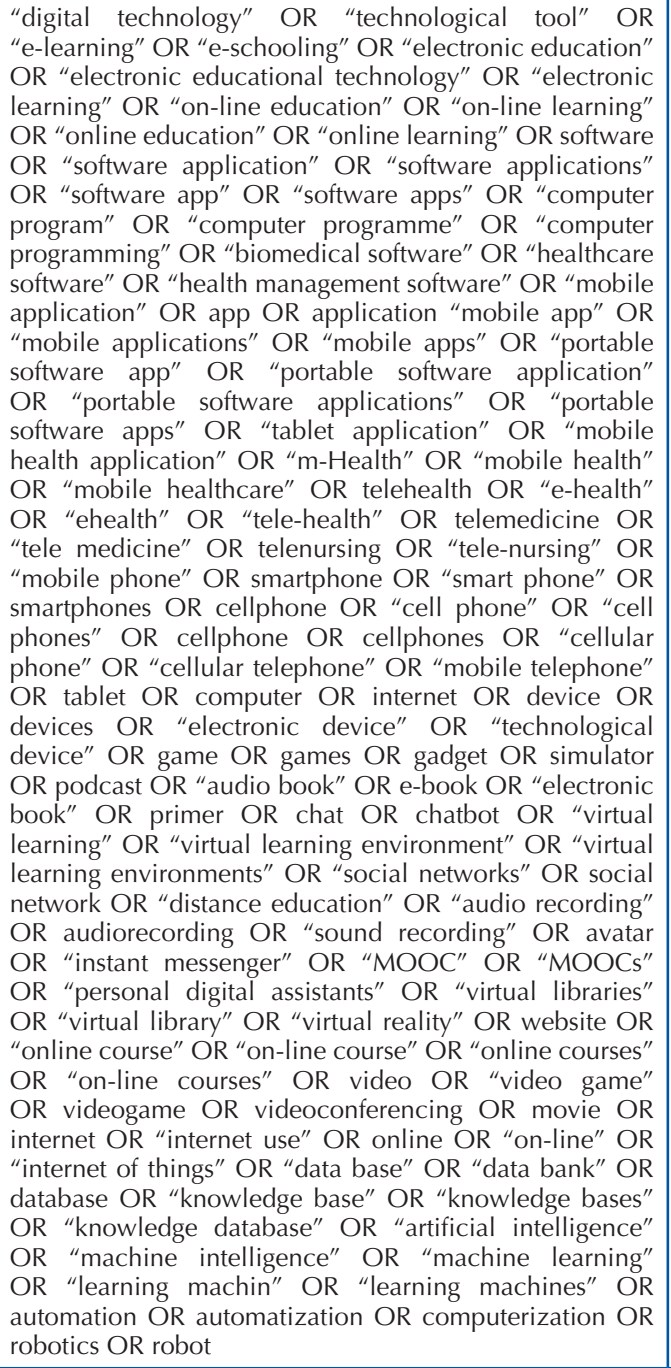 & $\begin{array}{l}\text { "coronavirus disease } 2019 \text { " OR "SARS-CoV-2 } \\
\text { infection" OR "SARS-CoV-2" OR "2019- } \\
\text { nCoV disease" OR "2019-nCoV infection" OR } \\
\text { "COVID 19" OR "COVID-19" OR "COVID } \\
2019 \text { " OR "nCoV } 2019 \text { disease" OR "nCoV } \\
2019 \text { infection" OR "novel coronavirus } \\
2019 \text { disease" OR "novel coronavirus } 2019 \\
\text { infection" OR "novel coronavirus disease } \\
2019 \text { " OR "novel coronavirus infection } \\
2019 \text { " OR "Wuhan coronavirus disease" OR } \\
\text { "Wuhan coronavirus infection" OR "Severe } \\
\text { acute respiratory syndrome coronavirus } \\
2 \text { " OR "2019 new coronavirus" OR "2019 } \\
\text { novel coronavirus" OR "2019-nCoV" OR } \\
\text { "HCoV-19" OR "human coronavirus } \\
2019 " \text { OR "nCoV-2019" OR "novel 2019 } \\
\text { Coronavirus" OR "novel coronavirus 2019" } \\
\text { OR "SARS Coronavirus 2" OR "SARS-CoV-2" } \\
\text { OR "Wuhan coronavirus" OR "Wuhan } \\
\text { seafood market pneumonia virus" }\end{array}$ \\
\hline Use & \multicolumn{3}{|c|}{ 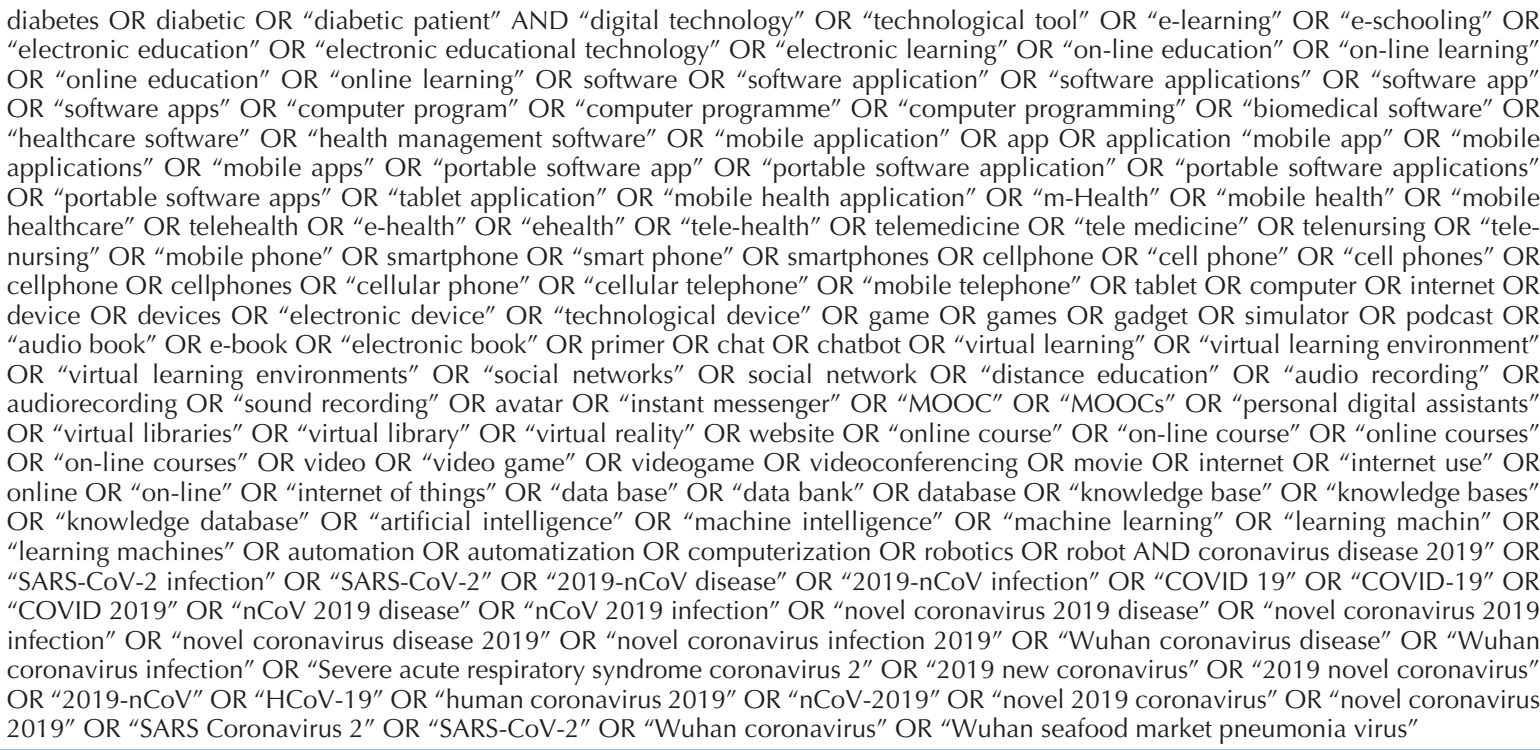 } \\
\hline
\end{tabular}


inclusion criteria were analyzed in the second phase, by reading the full manuscripts. Finally, manual searches were performed in the references of the included studies.

\section{Data Analysis and Treatment}

The selected studies were analyzed at different times for mapping (step 4). First, data were independently extracted by two reviewers using Microsoft Excel $^{\circledR}$ spreadsheets. The information was confirmed by the third reviewer and differences and doubts were resolved, in debates, until a consensus was reached among the authors. Information mapping took place based on the JBI instrument to characterize the studies ${ }^{(7)}$. The extraction chart included authorship, publication journal, country of origin, year of publication, objectives, design, sample number and main results regarding the identification of the technology used to monitor a person with DM. The description of the study characterization is presented in a table and tables, ending in a narrative synthesis.

\section{RESULTS}

The search identified 1,964 potentially relevant studies in the databases and other sources, of which 931 were removed because they were duplicates. Thus, 1,033 publications were analyzed by title and abstract, and 922 studies were excluded for not meeting the inclusion criteria. Therefore, 111 articles, along with reference lists, were fully assessed for eligibility. In the end, 22 documents were selected and a publication was added to the list of references, totaling 23 articles to compose the sample ${ }^{(12-34)}$.

Figure 1 shows the process of searching, excluding and selecting the studies found, according to the PRISMA$\mathrm{ScR}$ recommendations ${ }^{(8)}$.

Mostly, the articles were developed in Spain $(n=4)$, India $(\mathrm{n}=3)$ and Brazil $(\mathrm{n}=2)$, followed by studies published in the United States of America (USA), Singapore, United Kingdom, Israel, Italy, Australia, Colombia, Japan, Germany, France, Saudi Arabia, China, England and Greece, which published one article each. The documents were in English, being publications from $2021(\mathrm{n}=13)$ and $2020(\mathrm{n}=10)$.

As for journals, they were not limited to those specific to the areas of endocrinology and diabetes $(\mathrm{n}=18)$, but also in medicine $(n=4)$ and nursing $(n=1)$. The studies were crosssectional $(n=7)$, clinical observations $(n=1)$, case series $(n=1)$, cohort $(n=7)$, retrospective observational $(n=4)$, case reports $(n=1)$, randomized clinical trial $(n=2)$. A total of 8,001 people participated in the studies, of which 5,904 had type $2 \mathrm{DM}, 1,843$ type $1 \mathrm{DM}, 43$ had gestational DM, one had pancreatogenic DM, and 210 did not describe any type of DM (Chart 2).

The following are the main results and technologies used in the care of people with DM during the COVID-19 pandemic (Chart 3).

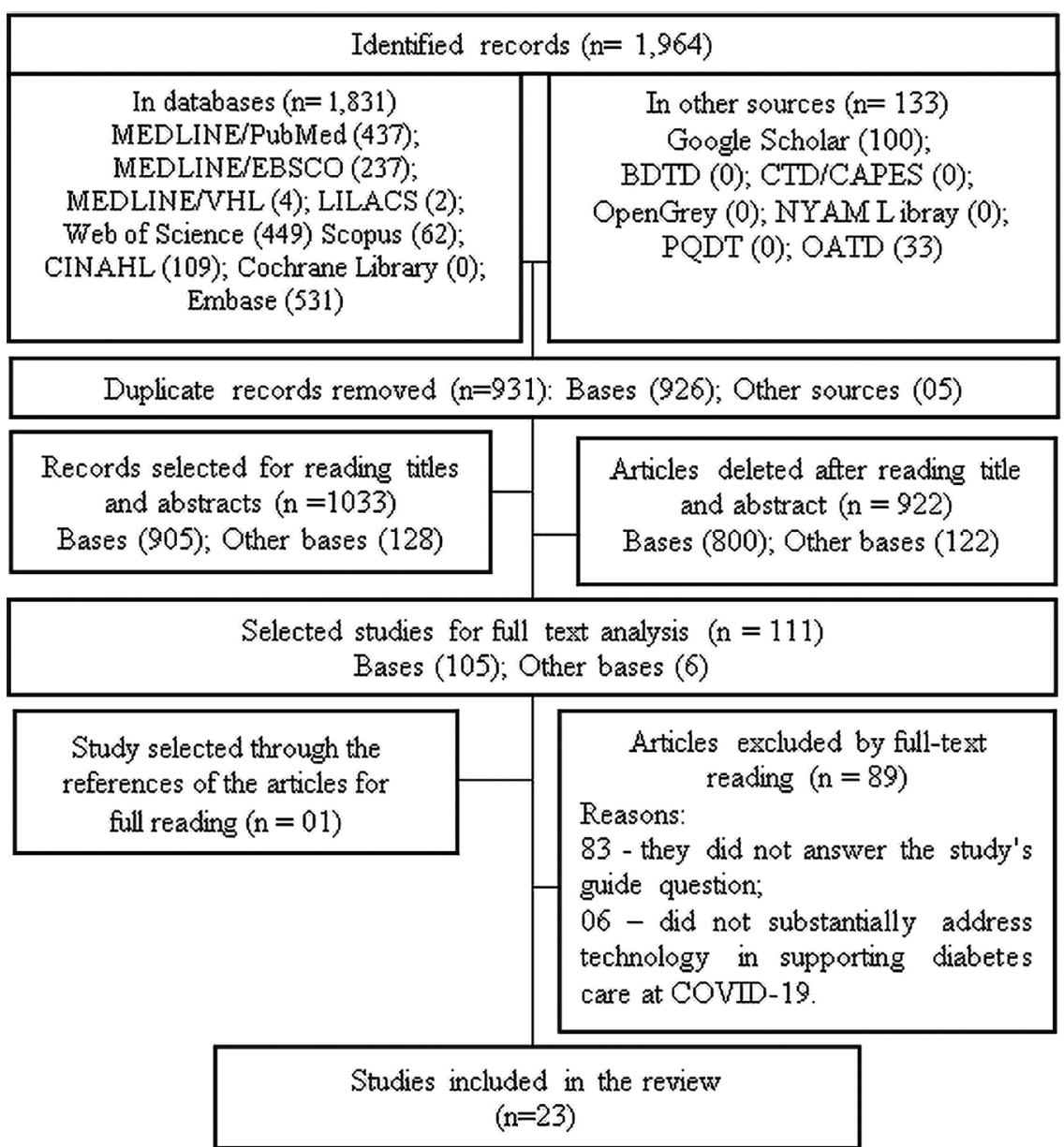

Figure 1 - Flowchart of selection of publications for scoping review according to PRISMA-ScR recommendations ${ }^{(8)}$. Fortaleza, CE, Brazil, 2021. 
Chart 2 - Characterization of articles included in this review. Fortaleza, CE, Brazil, 2021.

\begin{tabular}{|c|c|c|c|}
\hline Articles & Authors/Year/Country/Journal & Objectives & Design/sample \\
\hline 1. & $\begin{array}{l}\text { Albert et al., 2020 } \\
\text { Clin Pract. }\end{array}$ & $\begin{array}{l}\text { Describe the experience in remote management of women } \\
\text { with gestational diabetes mellitus (GDM) during the } \\
\text { COVID-19 pandemic. }\end{array}$ & Cross-sectional/20 women with GDM. \\
\hline 2. & Jiwani et al., $2021^{(13)} /$ USA/Geriatr Nurs. & $\begin{array}{c}\text { Assess the acceptability and experience of a participant of a } \\
\text { behavioral lifestyle intervention using Fitbit Technology in } \\
\text { older adults with overweight and obesity to manage type- } 2 \\
\text { diabetes mellitus (2DM) in the midst of the COVID-19 } \\
\text { pandemic. }\end{array}$ & Cross-sectional/18 elderly with 2DM. \\
\hline 3. & $\begin{array}{l}\text { Joshi et al., 2020(14)/India/Diabetes Res } \\
\text { Clin Pract. }\end{array}$ & $\begin{array}{l}\text { Describe a telemedicine approach for the follow-up } \\
\text { of people with DM under restrictions imposed by the } \\
\text { COVID-19 pandemic. }\end{array}$ & $\begin{array}{l}\text { Cross-sectional/103 people with DM, } \\
102 \text { with } 2 \text { and } 1 \text { DM with secondary } \\
\text { pancreatogenic DM. }\end{array}$ \\
\hline 4. & $\begin{array}{c}\text { Lim et al., 2020 } \\
\text { Health. }\end{array}$ & $\begin{array}{c}\text { Describe a nurse-led telehealth initiative to provide DM } \\
\text { care in adolescents during the } 2019 \text { coronavirus disease } \\
\text { pandemic. }\end{array}$ & $\begin{array}{l}\text { Clinical observations/35 adolescents, } \\
28 \text { with } 1 \mathrm{DM} \text { and } 72 \mathrm{DM} \text {. }\end{array}$ \\
\hline 5. & $\begin{array}{c}\text { Shin et al., } 2020^{(16)} / \text { UK and USA/ } \\
\text { Diabetes Care. }\end{array}$ & $\begin{array}{l}\text { Describe the two-center approaches to managing diabetic } \\
\text { foot ulcer problems to address the challenge presented by } \\
\text { the pandemic. }\end{array}$ & Case series/05 people with 2DM. \\
\hline 6. & $\begin{array}{c}\text { Rachmiel et al., } 2021^{(17) / / \text { srael/Acta }} \\
\text { Diabetol. }\end{array}$ & $\begin{array}{l}\text { Assess the feasibility of carrying out a single multidisciplinary } \\
\text { telehealth intervention and its short-term impact on blood } \\
\text { glucose metrics in young people with 1DM. }\end{array}$ & $\begin{array}{l}\text { Real-life observational multicenter } \\
\text { cohort study/195 people with 1DM. }\end{array}$ \\
\hline 7. & $\begin{array}{l}\text { Predieri et al., } 2020^{(18)} / \text { Italy/Front } \\
\text { Endocrinol (Lausanne). }\end{array}$ & $\begin{array}{l}\text { Investigate the effects of changes in daily routine, due } \\
\text { to COVID-19 blockade, on glycemic management, in } \\
\text { a cohort of children and adolescents with 1DM using } \\
\text { continuous glucose monitoring in real time. }\end{array}$ & $\begin{array}{l}\text { Observational, retrospective } \\
\text { longitudinal study/ } 62 \text { children and } \\
\text { adolescents with } 1 \mathrm{DM} \text {. }\end{array}$ \\
\hline 8. & $\begin{array}{l}\text { Kavitha et al., } 2020^{(19)} / \text { India/Diabetes } \\
\text { Metab Syndr. }\end{array}$ & $\begin{array}{l}\text { Discuss the pros and cons of telemedicine or "tele- } \\
\text { podiatry" in diabetic foot treatment. }\end{array}$ & $\begin{array}{l}\text { Report of three cases/03 people with } \\
2 \mathrm{DM} \text { and diabetic foot ulcer. }\end{array}$ \\
\hline 9. & $\begin{array}{l}\text { Varnfield et al., } 2021^{(20)} / \text { Australia/ } \\
\text { Diabetes Technol Ther. }\end{array}$ & $\begin{array}{l}\text { Assess the adoption and coordination of multidisciplinary } \\
\text { care of a mHealth platform called M } \mathrm{M} \text { THer, in a cohort of } \\
\text { women with an initial diagnosis of GDM. }\end{array}$ & Cohort study/23 women with GDM. \\
\hline 10. & $\begin{array}{l}\text { Tejera-Perez et al., } 2021^{(21)} / \text { Spain/ } \\
\text { Diabetes Res Clin Pract. }\end{array}$ & $\begin{array}{l}\text { Analyze the effects of confinement between people with } \\
\text { type-1 diabetes (1DM) and their caregivers during the } \\
\text { COVID-19 crisis and contemporary changes in medical } \\
\text { care and patient preferences. }\end{array}$ & $\begin{array}{l}\text { Cross-sectional/769 individuals } \\
\text { participated in the research (603 } \\
\text { people with } 1 \mathrm{DM} \text { and } 166 \text { caregivers). }\end{array}$ \\
\hline 11. & $\begin{array}{l}\text { Gómez et al., } 2021^{(22)} / \text { Colombia/ } \\
\text { Diabetes Metab Syndr. }\end{array}$ & $\begin{array}{l}\text { Describe the efficacy and safety results of the virtual } \\
\text { training program. }\end{array}$ & $\begin{array}{l}\text { Prospective cohort/91 people with } \\
\text { 1DM. }\end{array}$ \\
\hline 12. & $\begin{array}{l}\text { Onishi et al., } 2021^{(23) / J a p a n / J ~ D i a b e t e s ~} \\
\text { Investig. }\end{array}$ & $\begin{array}{c}\text { Assess the effect of telemedicine and the clinic visit on } \\
\text { glycated hemoglobin (HbA1c) during coronavirus disease } \\
\text { emergency state in } 2019 .\end{array}$ & $\begin{array}{c}\text { Retrospective cohort } / 2,727 \text { people, } \\
\text { of which } 2,556 \text { had } 2 \mathrm{DM} \text { and the } \\
\text { remainder }(\mathrm{n}=171) \text { did not describe } \\
\text { the type. }\end{array}$ \\
\hline 13. & $\begin{array}{c}\text { Alessi et al., } 2021^{(24)} / \text { Brazil/Acta } \\
\text { Diabetol. }\end{array}$ & $\begin{array}{c}\text { Assess the impact of teleintervention on mental health } \\
\text { parameters in patients with 2DM during the coronavirus } \\
\text { disease pandemic in } 2019 .\end{array}$ & $\begin{array}{l}\text { Randomized clinical trial/91 people } \\
\text { with 2DM participated ( } 46 \text { from the } \\
\text { intervention group and } 45 \text { from the } \\
\text { control group). }\end{array}$ \\
\hline 14. & $\begin{array}{c}\text { Braune et al., } 2021^{(25)} / \text { Germany/JMIR } \\
\text { Mhealth Uhealth. }\end{array}$ & Remotely support children with 1DM and their caregivers. & $\begin{array}{l}\text { Prospective cohort } / 28 \text { children with } \\
\text { 1DM. }\end{array}$ \\
\hline 15. & $\begin{array}{c}\text { Flocard et al., 2021 } \\
\text { des Maladies Metaboliques. }\end{array}$ & $\begin{array}{l}\text { Assess the glycemic balance at three and six months } \\
\text { of patients with DM followed up by teleconsultation, } \\
\text { compared to the group of patients who did not undergo } \\
\text { teleconsultation. }\end{array}$ & $\begin{array}{l}\text { Prospective cohort/Of the } 491 \\
\text { participants, } 145 \text { had 1DM, } 307 \text { 2DM } \\
\text { and } 39 \text { other types of DM }\end{array}$ \\
\hline 16. & $\begin{array}{c}\text { Tourkmani et al., } 2021^{(27)} / \text { Saudi Arabia/ } \\
\text { J Telemed Telecare. }\end{array}$ & $\begin{array}{l}\text { Determine the effect of a virtual integrated care clinic on } \\
\text { glycemic management among high-risk patients with 2DM } \\
\text { in a chronic disease center in Saudi Arabia. }\end{array}$ & $\begin{array}{l}\text { Prospective study of a single cohort } \\
\text { before and after the intervention/130 } \\
\text { people with 2DM. }\end{array}$ \\
\hline 17. & $\begin{array}{c}\text { Kang et al., } 2021^{(28)} / \text { China/Primary Care } \\
\text { Diabetes. }\end{array}$ & $\begin{array}{l}\text { Conduct a randomized controlled trial to confirm the } \\
\text { effectiveness of remote management, using a cell phone's } \\
\text { WeChat app, in comprehensive DM management during } \\
\text { the COVID-19 pandemic. }\end{array}$ & $\begin{array}{l}\text { Randomized clinical trial } / 160 \\
\text { people with } 2 \mathrm{DM} \text { ( } 80 \text { cases to the } \\
\text { intervention group and } 80 \text { cases to the } \\
\text { control group). }\end{array}$ \\
\hline 18. & $\begin{array}{c}\text { Matheus et al., 2020 } \\
\text { Endocrinol Metab }\end{array}$ & $\begin{array}{l}\text { Assess the performance of telemonitoring in the detection } \\
\text { of clinical and psychological needs and in the adhering } \\
\text { to the protection measures imposed by the COVID-19 } \\
\text { pandemic, in addition to remote care for patients with } \\
\text { 1DM, in a public university center in Brazil. }\end{array}$ & Cross-sectional/237 people with 1DM. \\
\hline 19. & Viñals et al., 2021 ${ }^{(30)} /$ Spain/Acta Diabetol & $\begin{array}{c}\text { Assess glucose profile management by patients with 1DM, } \\
\text { with a tendency to hypoglycemia, using a sensor-enhanced } \\
\text { pump. }\end{array}$ & $\begin{array}{c}\text { Observational and retrospective/59 } \\
\text { people with 1DM. }\end{array}$ \\
\hline
\end{tabular}




\section{...continuation}

\begin{tabular}{|c|c|c|c|}
\hline Articles & Authors/Year/Country/Journal & Objectives & Design/sample \\
\hline 20. & $\begin{array}{c}\text { Navis et al., } 2021^{(31)} / \text { England/Acta } \\
\text { Diabetol. }\end{array}$ & $\begin{array}{c}\text { Analyze and compare glycemic results before and during } \\
\text { blockade in a cohort of people with 1DM using flash and } \\
\text { continuous glucose monitors. }\end{array}$ & $\begin{array}{l}\text { Retrospective, observational and } \\
\text { unicentric assessment/269 people } \\
\text { with } 1 \mathrm{DM} \text {. }\end{array}$ \\
\hline 21. & $\begin{array}{c}\text { Anjana et al., } 2020^{(32)} / \text { India/Diabetes } \\
\text { Technol Ther. }\end{array}$ & $\begin{array}{l}\text { Assess the effects of a prolonged blockade on the adoption } \\
\text { of newer technologies (including telemedicine services) and } \\
\text { changes in glycemic management in patients with type } 2 \\
\text { DM treated at a private tertiary DM treatment center in India. }\end{array}$ & $\begin{array}{c}\text { Cross-sectional/2,510 people with } \\
\text { 2DM. }\end{array}$ \\
\hline 22. & $\begin{array}{c}\text { Christoforidis et al., } 2020^{(33)} / \text { Greece/ } \\
\text { Diabetes Res Clin Pract. }\end{array}$ & $\begin{array}{c}\text { Monitor the effect of coronavirus block age on DM } \\
\text { management in children with type } 1 \text { DM using an insulin } \\
\text { pump equipped with a continuous glucose } \\
\text { monitoring system. }\end{array}$ & $\begin{array}{c}\text { Cross-sectional/34 children with } \\
\text { 1DM. }\end{array}$ \\
\hline 23. & $\begin{array}{c}\text { Mesa et al., 2020(34)/Spain/Diabetes Res } \\
\text { Clin Pract. }\end{array}$ & $\begin{array}{l}\text { Examine the impact of the exceptional scenario on the } \\
\text { glucose profile of patients with 1DM prone to hypoglycemia, } \\
\text { using independent continuous glucose monitoring. }\end{array}$ & $\begin{array}{l}\text { Observational and retrospective/ } \\
92 \text { people with 1DM. }\end{array}$ \\
\hline
\end{tabular}

Chart 3 - Synthesis of mapped articles, according to main results and digital technologies identified in diabetes care. Fortaleza, CE, Brazil, 2021.

\begin{tabular}{|c|c|c|}
\hline Article & Main results & Digital technologies identified \\
\hline 1. & $\begin{array}{l}\text { The SineDie app can avoid unnecessary hospital visits, maintaining the best } \\
\text { quality of health and reducing physicians' workload for managing GDM. }\end{array}$ & $\begin{array}{l}\text { SineDie for Android phone with artificial intelligence that } \\
\text { automatically classifies and analyzes data. }\end{array}$ \\
\hline 2. & $\begin{array}{l}\text { Personal fitness technology }\left(\text { Fitbit }^{\circledR}\right) \text { has the potential to improve } 2 \mathrm{DM} \\
\text { management. }\end{array}$ & $\begin{array}{l}\text { Complementary personal fitness app }\left(\mathrm{Fitbit}^{\circledast}\right) \text { was downloaded to } \\
\text { each person's phone, with the support of the research team. }\end{array}$ \\
\hline 3. & $\begin{array}{l}\text { The strategy of using telemedicine, through a team of trained physicians, } \\
\text { is an efficient way to provide patient care amidst COVID-19's blockade } \\
\text { restrictions. }\end{array}$ & Telemedicine provided real-time audio consultations over the phone. \\
\hline 5. & $\begin{array}{l}\text { The adoption and widespread use of virtual telemedicine consultations } \\
\text { proved to be successful, many hospital admissions and treatments were } \\
\text { avoided. }\end{array}$ & Telemedicine for monitoring patients with diabetic foot ulcers. \\
\hline 6. & $\begin{array}{l}\text { Pediatric patients and young adults with 1DM benefited from a telehealth } \\
\text { visit during the COVID-19 pandemic. }\end{array}$ & $\begin{array}{l}\text { Telehealth included video, telephone and email modalities. Data } \\
\text { retrieved from medical files, continuous glucose monitoring systems, } \\
\text { and continuous subcutaneous insulin infusion sets (pumps) acquired } \\
\text { by Dexcom Clarity, CareLink, and Tidepool softwares. }\end{array}$ \\
\hline 8. & $\begin{array}{l}\text { Telemedicine or tele-podiatry was effective in managing low-risk individuals } \\
\text { with diabetic foot ulcers and useful in referring high-risk individuals to } \\
\text { hospital visits, facilitating adequate management. }\end{array}$ & $\begin{array}{l}\text { Telemedicine in the management of diabetic foot were: e-mail, } \\
\text { images shared by e-mail or online, text messaging application, video } \\
\text { call application and messages and audio call. }\end{array}$ \\
\hline 9. & $\begin{array}{l}\text { The MOTHer mHealth platform for the health care of women with GDM } \\
\text { can provide an effective new way to improve multidisciplinary care in the } \\
\text { face of COVID-19 disruptions. }\end{array}$ & $\begin{array}{l}\text { The MऽTHer app integrates multimedia content delivery via } \\
\text { smartphone (iOS/Android), data entry to support women managing } \\
\text { GDM from diagnosis to delivery. }\end{array}$ \\
\hline 10. & $\begin{array}{l}\text { Almost all participants agreed with the concept of telemedicine, favoring } \\
\text { the telephone and video calls as the preferred means of communication. }\end{array}$ & $\begin{array}{l}\text { Telehealth used the telephone and video calls as means of } \\
\text { communication and was assessed through a questionnaire by } \\
\text { patients with 1DM during the COVID-19 pandemic. }\end{array}$ \\
\hline 11. & $\begin{array}{l}\text { Virtual training and follow-up using the Carelink platform allows physicians } \\
\text { to provide education and is an appropriate option in situations that limit } \\
\text { patient access to follow-up centers. }\end{array}$ & $\begin{array}{l}\text { Virtual training and follow-up were performed using the Zoom } \\
\text { videoconference application and Medtronic Carelink System } \\
\text { software, version 3.1. }\end{array}$ \\
\hline
\end{tabular}

continue.. 
...continuation

\begin{tabular}{|c|c|c|}
\hline Article & Main results & Digital technologies identified \\
\hline 15. & $\begin{array}{l}\text { Monitoring through telemedicine makes it possible to ensure the follow- } \\
\text { up of patients, while extending the time interval between one-to-one } \\
\text { consultations, it also facilitates access to care for everyone and limits the } \\
\text { movement of patients further away from care structures. }\end{array}$ & Teleconsultation was assessed using a questionnaire. \\
\hline 16. & $\begin{array}{l}\text { Telemedicine was effective in providing adequate care for patients with } \\
\text { DM, especially when usual self-care was not possible during the COVID-19 } \\
\text { pandemic. }\end{array}$ & $\begin{array}{l}\text { Virtual consultations were used, in calls for staff to communicate } \\
\text { with patients. WhatsApp was used to provide written instructions, } \\
\text { educational materials, audiovisual resources and more. Short text } \\
\text { messaging services were also used. }\end{array}$ \\
\hline 17. & $\begin{array}{l}\text { Using the WeChat app during remote management can improve the target } \\
\text { glucose rate without increasing the risk of hypoglycemia. }\end{array}$ & WeChat App was used during remote query. \\
\hline 18. & $\begin{array}{l}\text { Monitoring 1DM patients during the pandemic helped to reduce the need } \\
\text { for one-to-one consultations, detect clinical and psychological needs and } \\
\text { support patients, in addition to monitoring suspected cases of COVID-19 } \\
\text { and adherence to protective measures. }\end{array}$ & $\begin{array}{l}\text { Teleconsultation obtained clinical data, presence of COVID-19 } \\
\text { symptoms, lifestyle habits, psychological effects of the pandemic, in } \\
\text { addition to the need for support from a mental health professional. }\end{array}$ \\
\hline 19. & $\begin{array}{l}\text { The very restrictive blocking conditions imposed by the COVID-19 } \\
\text { pandemic can be successfully managed in terms of glycemic management } \\
\text { by the hypoglycemic-prone } 1 \mathrm{DM} \text { population using the advanced sensor- } \\
\text { augmented pump. }\end{array}$ & $\begin{array}{l}\text { Review of electronic medical records and databases of individuals } \\
\text { with 1DM followed at the DM Unit. }\end{array}$ \\
\hline 20. & $\begin{array}{l}\text { The study showed that sensor-based glycemic outcomes improve during the } \\
\text { block period in people with DM equipped with a glucose sensor. }\end{array}$ & $\begin{array}{l}\text { Data were collected from electronic outpatient records and web- } \\
\text { based glucose monitoring platforms (Libreview; Abbott diabetes care } \\
\text { and Dexcom clarity; Dexcom Inc). }\end{array}$ \\
\hline 21. & $\begin{array}{l}\text { Acceptance of telemedicine facilities remains sub-optimal even among } \\
\text { the relatively wealthier Asian Indian population during the COVID-19 } \\
\text { pandemic and subsequent blockade, despite high levels of satisfaction } \\
\text { among those who used it. }\end{array}$ & $\begin{array}{l}\text { Telemedicine was assessed using a structured questionnaire about } \\
\text { preference for online support facilities and use of blood glucose self- } \\
\text { monitoring equipment. }\end{array}$ \\
\hline 22. & $\begin{array}{l}\text { Glycemic management during coronavirus blockade can be adequately } \\
\text { achieved and be comparable to the pre-blockade period in children with } \\
\text { 1DM using a sensor-equipped insulin pump. }\end{array}$ & $\begin{array}{l}\text { Monitoring tools were Medtronic MiniMed 640G Insulin, } \\
\text { accompanied with EnliteTM sensor and GuardianTM } 2 \text { Link } \\
\text { transmitter to load the data into the CareLink system. }\end{array}$ \\
\hline 23. & $\begin{array}{l}\text { The blocking conditions imposed by the COVID-19 pandemic can } \\
\text { be successfully managed, in terms of glycemic management, by the } \\
\text { hypoglycemic-prone 1DM population using continuous glucose monitoring. }\end{array}$ & $\begin{array}{l}\text { Review of patient charts using multiple daily injections and a } \\
\text { Dexcom G5 } 5^{\circledast} \text { or FreeStyle Libre } \text { continuous glucose monitoring }^{\circledast} \\
\text { system. Anonymous data from the Clarity }{ }^{\circledast} \text { or Libreview } \text { platforms }^{\circledast} \text { plate also used. }\end{array}$ \\
\hline
\end{tabular}

\section{DISCUSSION}

This review showed that restrictions arising from COVID-19 provided increased use of telemedicine or telehealth or remote care for the front line in DM management. During the pandemic period, technological innovations in healthcare and the development of new devices to store and transfer web-based data further enable the exchange of information between patients, families and healthcare professionals.

Overall, the effectiveness of virtual visits, through phone calls, text messages, mobile applications or electronic visits, in the context of the COVID-19 pandemic, was described in the studies in this review ${ }^{(12-34)}$. Additionally, the literature reinforces the evidence that virtual consultations can lead to adequate care during a pandemic or when a one-to-one visit cannot be carried out for any reason. Data sharing and remote visits help maintain or achieve adequate glycemic management through data analysis and therapy adjustments ${ }^{(35)}$.

Furthermore, it was observed that several professional categories that were involved in the research scenarios, as a physician, nurses, podiatrists, diabetologists, nutritional educators, psychologists, social workers and pharmacists, shared decisions on therapeutic adjustments and on the development of educational actions to convince patients to maintain a healthy lifestyle. Research from the United Kingdom has shown that, with increasing familiarity with established systems, DM health professionals will be more open to adopt virtual care in routine practice and can be an opportunity for shared care between people with DM and the team. Several members of the multidisciplinary DM team can meet for videoconference, make collaborative decisions with patients, in order to result in more effective, safer and quality care ${ }^{(36)}$.

Among the studies that address the care of people with 2DM, there are those with foot injuries, in facing the challenges posed by the pandemic ${ }^{(18,19)}$. Given this scenario, it is important that health services focus on the triad of care for people with diabetic foot ulcers: (1) keep these users out of hospitals in order to reduce exposure to risk and not overload the health system; (2) ensure the conditions so that care is guaranteed at home, considering an intervention plan that goes beyond the offer of medication, also contemplating food, functional, psychological and self-care aspects; and (3) provide security, in order to enable the good evolution of these individuals ${ }^{(37)}$.

Moreover, more than half of the selected studies reveal that remote monitoring, with the help of integrated web platforms, is an important tool to ensure the glycemic range at an adequate level among children, adolescents and young adults with $1 \mathrm{DM}^{(15,17-18,21-22,25-26,29-31,33-34)}$. Accordingly, a prospective observational study showed that structured virtual visits adequately maintain preexisting glycemic management or improve time in the target range among individuals with 1DM during an emergency, when one-to-one consultations are not allowed ${ }^{(35)}$.

The technology is known to have become essential during the COVID-19 pandemic. In times of isolation and social distance, the world trusted technology to learn, live and stay 
connected. Technology is best used to leverage and maintain children's social, physical, emotional, intellectual and spiritual well-being in an environment where children are engaged with an adult ${ }^{(38)}$. In this scenario, it is essential that family members or caregivers are involved in DM care plans, especially for the public of children and adolescents, who need family supervision and support to deal with technological innovations.

Mobile cell phone technologies, which carry clinical and glycemic data, proved useful during the pandemic and in remote care for women with $\mathrm{GDM}^{(12,20)}$. Furthermore, data from a series of cases stated that the use of gestational telediabetology aided with glucometers synchronized to cell phones stores data in the cloud for professionals to access, which can be considered in the management of hyperglycemia in pregnancy in the current scenario. Although it has advantages and disadvantages, telehealth for GDM management can be a useful tool in selected situations, in which patients are asymptomatic and clinically stable. More research is needed to study the benefits, risks, and care outcomes of gestational telediabetology $y^{(39)}$.

In the current decade, great efforts have been made to change the glucose detection system to internal monitoring and remote management of patients with $\mathrm{DM}^{(40)}$. To prevent the risk of coronavirus transmission, remote monitoring of glucose levels is necessary to provide personalized home care. Thus, the development of continuous personalized glucose monitoring attracted more attention during this pandemic to efficiently manage DM and prevent the spread of the coronavirus ${ }^{(41)}$. These results may attract the attention of healthcare professionals to explore not only continuous glucose monitoring devices, but also accurate and reliable continuous subcutaneous insulin infusion systems (pumps), which can stimulate patient compliance, seeking better DM management during the pandemic.

Therefore, in the context of these unprecedented times, the intervention of telemedicine, in support of continuous glucose monitoring, would be an ideal solution for DM management, which enables remote clinical consultation for patients with DM via glucose self-monitoring supported by personalized continuous glucose monitoring devices, not only favoring efficacy in DM treatment, but limiting exposure to the coronavirus among patients and professionals to contribute to global efforts against the coronavirus ${ }^{(40)}$. This review highlights current trends over the course of the pandemic period in terms of glucose measurement using different non-invasive techniques for real-time and/or archive glucose monitoring ${ }^{(17-18,22,25,31,32-34)}$.

Continuous glucose monitoring, which includes accurately tracking fluctuations in blood glucose levels without increasing the risk of exposure to coronavirus, it becomes an important strategy for DM self-management during the course of the pandemic, efficiently contributing to DM treatment and combating COVID-19(40). Furthermore, it is necessary that training on the use of pumps, sensors and carbohydrate counting be scheduled with specialists, including nutritionists and/or nurses. Thus, the educational role of virtual assistance is enhanced and access to technologies is favored despite the physical distance ${ }^{(42)}$.

It is also considered what critical and lasting consequence of the pandemic will be the accelerated adoption of digital technology in health care provision. In this context, it is found that DM care is an excellent example of the confluence of the pandemic and the growing importance of technology to transform care delivery and maximize results, despite the macro challenges ${ }^{(43)}$.

Given the above, it can be inferred that the technological revolution in the health area is a great ally for treatment of people with chronic conditions. It was observed, in general, that the use of technologies for the care of people with DM was enhanced in response to the new coronavirus pandemic. Health institutions had to innovate and manage the monitoring of people with DM, there is a growing expansion of new technologies available that, until recently, was not even thought to exist and are currently considered essential tools for DM self-care.

It is understood as limitations of this scoping review the fact that the onset of the pandemic and the intense flow of information on the subject hinder the availability of stable recommendations. The presence of studies without a robust methodological content increases the risk of information bias. In addition to this, choosing to select studies only on the first ten pages of Google Scholar has the possibility of omitting potentially relevant documents.

With the set of information highlighted in this study, it is expected to contribute to the construction of knowledge about technologies combined with DM treatment in times of the COVID-19 pandemic. As discussed, emerging changes in the universe are bearing fruit in the context of health, where the growing reliance on technology to provide care during a pandemic is transforming traditional ways of providing care and will likely result in a positive model of remote consultation, where appropriate, in the new post-pandemic world. The aim is also to encourage the scientific community to develop new studies, aiming at better understanding the applicability of digital technologies in DM, as well as assessing and increasing it from studies with a robust methodological design.

\section{CONCLUSION}

Telehealth, monitoring technologies, insulin delivery systems and communication devices were tools used to follow-up DM patients during the COVID-19 pandemic. Digital technologies were used in the care of people with severe DM during the COVID-19 pandemic. It is expected that this evolution will persist in the post-pandemic period, for monitoring and managing DM, in person or remotely, aiming at improving and continuing care for this disease.

\section{RESUMO}

Objetivo: Mapear as evidências sobre a utilização de tecnologias digitais no cuidado a pessoas com diabetes durante a pandemia de COVID-19. Método: Revisão de escopo, fundamentada no manual do JBI, que incluiu artigos científicos e literatura cinza oriunda de nove bancos de dados primários e sete secundários. Os artigos foram avaliados de forma independente por dois revisores. Utilizou-se o Rayyan ${ }^{\circledR}$ para seleção dos estudos. A descrição da caracterização dos estudos se encontra apresentada em tabela e quadros, findando em síntese narrativa. 
Resultados: Identificaram-se 1.964 estudos e, após seleção, restaram 23 publicações para análise. Revelou-se que a telemedicina foi utilizada em todos os estudos e as tecnologias de apoio à consulta remotas incluíam dispositivos de monitoramento de glicose contínuo, softrware de análise de dados de glicose, sistemas de aplicação de insulina, aplicativos, aparelhos de comunicação áudio e/ou voz, que facilitaram o acompanhamento e o gerenciamento remoto do diabetes mellitus. Conclusão: Telessaúde, tecnologias de monitoramento, sistemas de aplicação de insulina e aparelhos de comunicação foram ferramentas utilizadas para o acompanhamento dos pacientes com diabetes durante a pandemia.

\section{DESCRITORES}

Tecnologia; Tecnologia Educacional; Aplicativos Móveis; Infecções por Coronavírus; Síndrome Respiratória Aguda Grave; Diabetes Mellitus.

\section{RESUMEN}

Objetivo: Mapear la evidencia sobre el uso de tecnologías digitales en la atención de personas con diabetes durante la pandemia de COVID-19. Método: Revisión del alcance, basada en el manual del JBI, que incluyó artículos científicos y literatura gris de nueve bases de datos primarias y siete secundarias. Los artículos fueron evaluados de forma independiente por dos revisores. Se utilizó Rayyan ${ }^{\circledR}$ para la selección de estudios. La descripción de la caracterización de los estudios se presenta en tabla y tablas, finalizando en una síntesis narrativa. Resultados: Se identificaron 1.964 estudios y, tras la selección, quedaron 23 publicaciones para análisis. Resultó que la telemedicina se utilizó en todos los estudios y las tecnologías de apoyo a la consulta remota incluyeron dispositivos de monitoreo continuo de glucosa, software de análisis de datos de glucosa, sistemas de administración de insulina, aplicaciones, dispositivos de comunicación de audio y/o voz, que facilitaron el control y el manejo remotos de la diabetes mellitus. Conclusión: La telesalud, las tecnologías de monitoreo, los sistemas de administración de insulina y los dispositivos de comunicación fueron herramientas utilizadas para monitorear a los pacientes con diabetes durante la pandemia.

\section{DESCRIPTORES}

Tecnología; Tecnología Educacional; Aplicaciones Móviles; Infecciones por Coronavirus; Síndrome Respiratorio Agudo Severo; Diabetes Mellitus.

\section{REFERENCES}

1. Celuppi IC, Lima GS, Rossi E, Wazlawick RS, Dalmarco EM. An analysis of the development of digital health technologies to fight COVID-19 in Brazil and the world. Cad Saude Pública. 2021;37(3):e00243220. DOI: https://doi.org/10.1590/0102-311x00243220

2. Abd-Alrazaq A, Hassan A, Abuelezz I, Ahmed A, Alzubaidi M, Shah U, Alhuwail D, Giannicchi A, Househ M. Overview of technologies implemented during the first wave of the COVID-19 pandemic: Scoping review. J Med Internet Res. 2021;23(9):e29136. DOI: https://doi. org/10.2196/29136

3. Lima-Martínez MM, Carrera Boada C, Madera-Silva MD, Marín W, Contreras M. COVID-19 e diabetes: Uma relação bidirecional. Clin Investig Arterioscler. 2021;33(3):151-57. DOI: https://doi.org/10.1016/j.arteri.2020.10.001

4. Nassar M, Nso N, Baraka B, Alfishawy M, Mohamed M, Nyabera A, Sachmechi I. The association between COVID-19 and type 1 diabetes mellitus: A systematic review. Diabetes Metab Syndr. 2021;15(1):447-54. DOI: https://doi.org/10.1016/j.dsx.2021.02.009

5. Corona G, Pizzocaro A, Vena W, Rastrelli G, Semearo F, Isidori AM, et al. Diabetes is most important cause for mortality in COVID-19 hospitalized patients: Systematic review and meta-analysis. Rev Endocr Metab Disord. 2021;22:275-96. DOI: https://doi.org/10.1007/s11154021-09630-8

6. Purnamayanti NKD, Wicaksana AL. Digital health services among patients with diabetes during the COVID-19 pandemic. Indian J Endocrinol Metab. 2021;2:86-91. DOI: https://doi.org/10.4103/ijem.ijem_153_21

7. Peters MDJ, Godfrey C, Mclnerney P, Munn Z, Tricco AC, Khalil H. Scoping reviews (2020 version). In: Aromataris E, Munn Z, editors. Joanna Briggs Institute manual for evidence synthesis. Adelaide: JBI; 2020.

8. Tricco AC, Lillie E, Zarin W, O'Brien KK, Colquhoun H, Levac D, et al. Prisma extension for scoping reviews (Prisma-ScR): checklist and explanation. Ann Intern Med. 2018;169(7):467-73. DOI: https://doi.org/10.7326/M18-0850

9. Arksey H, O'Malley L. Scoping studies: towards a methodological framework. Int J Soc Res Methodol. 2005;8:19-32. DOI: https://doi.org/10.10 80/1364557032000119616

10. Araújo WCO. Recuperação da informação em saúde: construção, modelos e estratégias. Convergências em Ciência da Informação. 2020;3(2): 100-34. DOI: https://doi.org/10.33467/conci.v3i2.13447

11. Ouzzani M, Hammady H, Fedorowicz Z, Elmagarmid A. Rayyan-a web and mobile app for systematic reviews. Systematic Reviews. 2016;5(1):210. DOI: https://doi.org/10.1186/s13643-016-0384-4

12. Albert L, Capel I, García-Sáez G, Martín-Redondo P, Hernando ME, Rigla M. Managing gestational diabetes mellitus using a smartphone application with artificial intelligence (SineDie) during the COVID-19 pandemic: Much more than just telemedicine. Diabetes Res Clin Pract. 2020;169:108396 DOI: https://doi.org/10.1016/j.diabres.2020.108396

13. Jiwani R, Dennis B, Bess C, Monk S, Meyer K, Wang J, et al. Assessing acceptability and patient experience of a behavioral lifestyle intervention using fitbit technology in older adults to manage type 2 diabetes amid COVID-19 pandemic: A focus group study. Geriatr Nurs. 2021;42(1):57-64. DOI: https://doi.org/10.1016/j.gerinurse.2020.11.007

14. Joshi R, Atal S, Fatima Z, Balakrishnan S, Sharma S, Joshi A. Diabetes care during COVID-19 lockdown at a tertiary care centre in India. Diabetes Res Clin Pract. 2020;166:108316. DOI: https://doi.org/10.1016/j.diabres.2020.108316

15. Lim ST, Yap F, Chin X. Bridging the needs of adolescent diabetes care during COVID-19: a nurse-led telehealth initiative. J Adolesc Health. 2020;67(4):615-7. DOI: https://doi.org/10.1016/j.jadohealth.2020.07.012

16. Shin L, Bowling FL, Armstrong DG, Boulton AJM. Saving the diabetic foot during the COVID-19 pandemic: a tale of two cities. Diabetes Care. 2020;43(8):1704-9. DOI: https://doi.org/10.2337/dc20-1176

17. Rachmiel M, Lebenthal Y, Mazor-Aronovitch K, Brener A, Levek N, Levran N, et al. Glycaemic control in the paediatric and young adult population with type 1 diabetes following a single telehealth visit - what have we learned from the COVID-19 lockdown? Acta Diabetol. 2021;58:697-705. DOI: https://doi.org/10.1007/s00592-021-01673-2 
18. Predieri B, Leo F, Candia F, Lucaccioni L, Madeo SF, Pugliese M, et al. Glycemic control improvement in Italian children and adolescents with type 1 diabetes followed through telemedicine during lockdown due to the COVID-19 pandemic. Front Endocrinol (Lausanne). 2020;11:595735. DOI: https://doi.org/10.3389/fendo.2020.595735

19. Kavitha KV, Deshpande SR, Pandit AP, Unnikrishnan AG. Application of tele-podiatry in diabetic foot management: a series of illustrative cases. Diabetes Metab Syndr. 2020;14(6):1991-5. DOI: https://doi.org/10.1016/j.dsx.2020.10.009

20. Varnfield M, Redd C, Stoney RM, Higgins L, Scolari N, Warwick R, et al. M $\nabla$ THer, an mHealth system to support women with gestational diabetes mellitus: feasibility and acceptability study. Diabetes Technol Ther. 2021;23(5):358-66. DOI: https://doi.org/10.1089/dia.2020. 0509

21. Tejera-Perez C, Moreno-Pérez Ó, Rios J, Reyes-García R. People living with type 1 diabetes point of view in COVID-19 times (COVIDT1 study): disease impact, health system pitfalls and lessons for the future. Diabetes Res Clin Pract. 2021;171:108547. DOI: https://doi.org/10.1016/j. diabres.2020.108547

22. Gómez AM, Henao D, Parra D, Kerguelen A, Pinilla MV, Muñoz OM, et al. Virtual training on the hybrid close loop system in people with type 1 diabetes (T1D) during the COVID-19 pandemic. Diabetes Metab Syndr. 2021;15(1):243-7. DOI: https://doi.org/10.1016/j.dsx.2020. 12.041

23. Onishi Y, Yoshida Y, Takao T, Tahara T, Kikuchi T, Kobori T, et al. Diabetes management by either telemedicine or clinic visit improved glycemic control during the coronavirus disease 2019 pandemic state of emergency in Japan. J Diabetes Investig. 2021 Mar:1-5. DOI: https://doi.org/10.1111/ jdi.13546

24. Alessi J, Oliveira GB, Franco DW, Becker AS, Knijnik CP, Kobe GL, et al. Telehealth strategy to mitigate the negative psychological impact of the COVID-19 pandemic on type 2 diabetes: A randomized controlled trial. Acta Diabetol. 2021;58:899-909. DOI: https://doi.org/10.1007/s00592021-01690-1

25. Braune K, Boss K, Schmidt-Herzel J, Gajewska KA, Thieffry A, Schulze L, et al. Shaping workflows in digital and remote diabetes care during the covid-19 pandemic via service design: prospective, longitudinal, open-label feasibility trial. JMIR Mhealth Uhealth. 2021;9(4):e24374. DOI: https://doi.org/10.2196/24374

26. Flocard M, Meyer L, Fabacher T, Bahougne T, Ortéga F, Paris D, et al. Prise en charge par téléconsultation des patients diabétiques dans le contexte de la pandémie de la COVID-19: étude prospective observationnelle. Médecine Des Maladies Métaboliques. 2021;15(1):24-32. DOI: https://doi. org/10.1016/j.mmm.2020.11.002

27. Tourkmani AM, ALHarbi TJ, Rsheed AMB, Alrasheedy AA, ALMadani W, ALJuraisi F, et al. The impact of telemedicine on patients with uncontrolled type 2 diabetes mellitus during the COVID-19 pandemic in Saudi Arabia: findings and implications. J Telemed Telecare. 2021 Feb:1. DOI: https:// doi.org/10.1177/1357633X20985763

28. Kang J, Chen Y, Zhao Y, Zhang C. Effect of remote management on comprehensive management of diabetes mellitus during the COVID-19 epidemic. Prim Care Diabetes. 2021;15(3):417-23. DOI: https://doi.org/10.1016/j.pcd.2020.12.004

29. Matheus ASM, Cabizuca CA, Tannus LRM, Passos AC, Schmidt AC, Gouveia AT, et al. Telemonitoring type 1 diabetes patients during the COVID-19 pandemic in Brazil: was it useful? Arch Endocrinol Metab. 2020;65(1):105-11. DOI: https://doi.org/10.20945/2359-3997000 000309

30. Viñals C, Mesa A, Roca D, Vidal M, Pueyo I, Conget I, et al. Management of glucose profile throughout strict COVID-19 lockdown by patients with type 1 diabetes prone to hypoglycaemia using sensor-augmented pump. Acta Diabetol. 2021;58(3):383-8. DOI: https://doi.org/10.1007/ s00592-020-01625-2

31. Navis JP, Leelarathna L, Mubita W, Urwin A, Rutter MK, Schofield J, et al. Impact of COVID-19 lockdown on flash and real-time glucose sensor users with type 1 diabetes in England. Acta Diabetol. 2021;58(2):231-7. DOI: https://doi.org/10.1007/s00592-020-01614-5

32. Anjana RM, Pradeepa R, Deepa M, Jebarani S, Venkatesan U, Parvathi SJ, et al. Acceptability and utilization of newer technologies and effects on glycemic control in type 2 diabetes: lessons learned from lockdown. Diabetes Technol Ther. 2020;22(7):527-34. DOI: https://doi.org/10.1089/ dia.2020.0240

33. Christoforidis A, Kavoura E, Nemtsa A, Pappa K, Dimitriadou M. Coronavirus lockdown effect on type 1 diabetes management on children wearing insulin pump equipped with continuous glucose monitoring system. Diabetes Res Clin Pract. 2020;166:108307. DOI: https://doi.org/10.1016/j. diabres.2020.108307

34. Mesa A, Viñals C, Pueyo I, Roca D, Vidal M, Giménez M, et al. The impact of strict COVID-19 lockdown in Spain on glycemic profiles in patients with type 1 diabetes prone to hypoglycemia using standalone continuous glucose monitoring. Diabetes Res Clin Pract. 2020;167:108354. DOI: https://doi.org/10.1016/j.diabres.2020.108354

35. Parise M, Tartaglione L, Cutruzzolà A, Maiorino MI, Esposito K, Pitocco D, et al. Teleassistance for patients with type 1 diabetes during the COVID-19 pandemic: results of a pilot study. J Med Internet Res. 2021;23(4):e24552. DOI: https://doi.org/10.2196/24552

36. Quinn LM, Davies MJ, Hadjiconstantinou M. Virtual consultations and the role of technology during the COVID-19 pandemic for people with type 2 diabetes: the UK perspective. J Med Internet Res. 2020;22(8):e21609. DOI: https://doi.org/10.2196/21609

37. Cerqueira MMBF, Merces MC, Cerqueira JMF, Silva DAR, Almeida OS, Gomes AMT. Proposals on self-care for diabetic foot during the COVID-19 pandemic in Brazil. Acta Paulista de Enfermagem. 2020;33:e-EDT20200005. DOI: https://doi.org/10.37689/acta-ape/2020EDT0005

38. Goldschmidt K. The COVID-19 pandemic: technology use to support the wellbeing of children. J Pediatr Nurs. 2020;53:88-90. DOI: https://doi. org/10.1016/j.pedn.2020.04.013

39. Simon MR, Sarkar N, Kumaran S, Chittake A, Purandare V, Unnikrishnan AG. Telemedicine for the initial management of newly diagnosed gestational diabetes in the pandemic period: a report of three case studies. Journal of Diabetology. 2020;11(3):144-7. DOI: https://doi.org/10.4103/ JOD.JOD_44_20

40. Phan LMT, Vo TAT, Hoang TX, Selvam SP, Pham HL, Kim JY, et al. Trending technology of glucose monitoring during COVID-19 pandemic: challenges in personalized healthcare. Adv Mater Technol. 2021;2100020:1-21. DOI: https://doi.org/10.1002/admt.202100020 
41. Shehav-Zaltzman G, Segal G, Konvalina N, Tirosh A. Remote glucose monitoring of hospitalized, quarantined patients with diabetes and COVID-19. Diabetes Care. 2020;43(7):e75-e76. DOI: https://doi.org/10.2337/dc20-0696

42. Vigersky RA, Velado K, Zhong A, Agrawal P, Cordero TL. The effectiveness of virtual training on the MiniMed ${ }^{\mathrm{TM}}$ 670G system in people with type 1 diabetes during the COVID-19 pandemic. Diabetes Technol Ther. 2021;23(2):104-9. DOI: https://doi.org/10.1089/dia.2020.0234

43. Garg S, Norman GJ. Impact of COVID-19 on health economics and technology of diabetes care: use cases of real-time continuous glucose monitoring to transform health care during a global pandemic. Diabetes Technol Ther. 2021;23(Suppl 1):S15-S20. DOI: https://doi.org/10.1089/ dia.2020.0656 